\title{
Two Mechanisms Drive Changes in Boreal Peatland Photosynthesis Following Long-Term Water Level Drawdown: Species Turnover and Altered Photosynthetic Capacity
}

\author{
Nicola Kokkonen, ${ }^{1}$ Anna M. Laine, ${ }^{1,2}$ Elisa Männistö, ${ }^{1}$ Lauri Mehtätalo, ${ }^{3,4}$ \\ Aino Korrensalo, ${ }^{1,4}$ and Eeva-Stiina Tuittila ${ }^{1 *}$
}

\begin{abstract}
${ }^{1}$ School of Forest Sciences, University of Eastern Finland, P.O. Box 111, 80101 Joensuu, Finland; ${ }^{2}$ Geological Survey of Finland, P.O. Box 1237, 70211 Kuopio, Finland; ${ }^{3}$ School of Computing, University of Eastern Finland, P.O. Box 111, 80101 Joensuu, Finland;

${ }^{4}$ Natural Resources Institute Finland, Yliopistokatu 6 B, 80100 Joensuu, Finland
\end{abstract}

\begin{abstract}
Climate change and the related increases in evapotranspiration threaten to make northern peatlands drier. The carbon sink function in peatlands is based on the delicate balance between the photosynthesis and decomposition. However, little is known about how existing and invading plant species will photosynthesize under drier conditions. The aim of this study is to quantify the long-term consequences of climate change-induced drying for peatland photosynthesis in the level of individual species and vegetation community. We measured the species-level photosynthesis of vascular plants and mosses characteristic for the three peatland types (rich fen, poor fen, bog) within a 16-year
\end{abstract}

Received 13 August 2021; accepted 9 December 2021; published online 15 February 2022

Supplementary Information: The online version contains supplementary material available at https://doi.org/10.1007/s10021-021-0073 6-3.

Author contributions EST and NK designed the study. NK, EM, AK and EST conducted the field measurements. Data analysis was performed by LM, NK and AML. NK and EST lead the writing of this manuscript with substantial contributions from AML, AK and EM.

*Corresponding author; e-mail: eeva-stiina.tuittila@uef.fi water level drawdown (WLD) experiment. Measurements were made in the laboratory from mesocosms collected from the field within the same day. We applied nonlinear mixed-effects models to test the impact of WLD on hyperbolic photosynthetic light response curve parameters. The model was then used to upscale photosynthesis to sitelevel. WLD impacted site-level photosynthesis through two mechanisms: species turnover and changes in species-level photosynthesis rate. The rich fen was the most sensitive and underwent major changes through both mechanisms; the vascular plant community shifted to woody plant dominance with higher rate of photosynthesis than the pre-treatment vegetation, and the rate of species-level photosynthesis increased significantly. The bog had a stable plant community with little change in photosynthesis, while the poor fen was an intermediate of the three peatland types. Our results suggest that vascular plants are the main drivers of site-level productivity changes, while mosses are more resistant to change. The change seems proportional to the availability of mineral nutrients, with higher nutrient status supporting vascular plant expansion. 
Key words: global change ecology; peatland; photosynthesis; water level draw-down; climate change; species turnover; light response; environmental change; fen; bog.

\section{HighLights}

- Long-term drying in peatlands alters the vegetation and site-level photosynthesis.

- The magnitude of change increases along with the availability of mineral nutrients.

- Vascular plants are the main drivers of changes, while mosses are more resistant.

\section{INTRODUCTION}

Undrained northern peatlands are currently a sink for atmospheric carbon (C) (Charman and others 2013) and have accumulated up to $30 \%$ of current global soil C over the Holocene (Gorham 1991; Turunen and others 2002; Yu and others 2011; Nichols and Peteet 2019). Although primary production in these ecosystems is low compared to northern forests (Dimitrov and others 2014), a cool climate and high water tables limit organic matter decomposition (Mäkilä and Saarnisto 2008) leading to the accumulation of peat deposits (Clymo 1984; Gorham 1991). However, ecosystem-level measurements have revealed annual variation in the size of the $C$ sink and have shown that in some years, peatlands turn into a $\mathrm{C}$ source due to lowered water tables (Rinne and others 2020a, b).

In the boreal region, the peatland $\mathrm{C}$ sink is threatened by climate change, which is projected to cause an increase in evapotranspiration rates (Helbig and others 2020) and more irregular precipitation (Donat and others 2016). This increased difference between precipitation and evapotranspiration is expected to result in an 8-22 cm water level drawdown (WLD) in northern peatlands (Gorham 1991; Roulet and others 1992; Gong and others 2012; Donat and others 2016). Recent palaeoecological studies show that such WLD is already ongoing (Swindles and others 2019) and has impacted plant community composition (Zhang and others 2020). Because both production and decomposition in peatlands are closely tied to water table position, climate change is likely to substantially impact peatland C dynamics (Loisel and others 2021).
The impact of WLD on microbial communities and related increases in rates of decomposition and respiration are already well known (Yrjälä and others 2011; Straková and others 2012; Peltoniemi and others 2015, 2016; Laine and others 2019), but the impact on photosynthesis is less clear and existing studies have reported contradictory results. These community-level studies, mostly based on chamber measurements, indicate both decreasing (Oechel and others 1998; Riutta and others 2007; Chivers and others 2009; Laine and others 2009; Munir and others 2015) and increasing (Strack and Waddington 2007; Ballantyne and others 2014; Munir and others 2014) photosynthesis as a response to WLD, which implies that the response is highly site-specific and can vary even within a peatland between microforms (Strack and others 2006; Harris and others 2020). Few comprehensive studies have examined the effects of drainage or drought on the photosynthesis rates of peatland plants at the species-level (Hájek and others 2009; Kangas and others 2014; Nijp and others 2014; Laine and others 2016; Jassey and Signarbieux 2019) which would allow for a mechanistic understanding of the response.

Working at the species-level in field conditions permits the separation of the two mechanisms that drive the response of site-level photosynthesis to WLD: change in the photosynthetic capacity of existing species (Hájek and others 2009; Kangas and others 2014), and species turnover during WLD-initiated succession (that is, vegetation succession) (Minkkinen and others 1999; Weltzin and others 2000; Strack and others 2006; Kokkonen and others 2019a, b). Following WLD, several key controls on plant photosynthesis are altered (Boisvenue and Running 2006; Ågren and others 2012; Fatichi and others 2014): The aerated peat layer deepens (Strack and others 2006; Whittington and Price 2006; Waddington and others 2015), which results in drier conditions for plants increasing the effective volume that roots can access, increased nutrient mineralization $(\mathrm{Bu}$ and others 2011; Straková and others 2012) and a decrease in soil and surface temperatures (Strack and others 2004; Straková and others 2012). To persist under these conditions following WLD, plants must acclimatize by changing leaf structure, seasonal development, stomatal ratio, and light use efficiency, thereby impacting photosynthetic potential (Boardman 1977; Smith and others 1997; Huner and others 1998; Basu and others 2016; Korrensalo and others 2016). Such trait plasticity, that is, the ability to modify structural mechanisms (Sultan 1995), is a likely process that allows generalist 
species, that is, species common to a large range of habitats, to persist and acclimatize to new conditions (Sultan 1995; Griffith and Sultan 2012). Specialist species, found only in a narrow range of habitats, typically lack this flexibility (Sultan 1995). In peatlands, the specialized plant species that grow in flarks or hollow habitats tend to disappear from the plant community after WLD, while peatland generalist or forest species invade (Minkkinen and others 1999; Hájek and others 2009; Kokkonen and others 2019a, b). Changes in photosynthetic capacity as an immediate response to WLD can be quantified using mesocosms or short-term in situ experiments, but long-term field-scale experiments are needed to capture the acclimation of photosynthetic capacity and the change that occurs due to the species turnover that take place slowly over years or decades (Minkkinen and others 1999; Sarkkola and others 2004; Kokkonen and others 2019a, b).

Here, we aim to quantify the changes in the photosynthesis of peatland plant communities following long-term WLD using a 15-year field experiment. To capture the variation in the response, we measured community composition and species-level photosynthesis of vascular plants and mosses in three peatland types: bog, poor fen, and rich fen. To assess the overall impact of moderate WLD on moss and vascular plant photosynthesis, we upscaled species-level photosynthesis measurements to the site-level using species biomass estimates at each site. We hypothesize that (1) WLD affects peatland plant photosynthesis through two mechanisms: acclimatization of species-level photosynthetic capacity and species turnover, and (2) the strength of the response increases, with nutrient availability, from bog to rich fen.

\section{MethodS}

\section{Site}

The experimental site is located at Lakkasuo, an eccentric raised mire complex in southern Finland $\left(61^{\circ} 47^{\prime} \mathrm{N} ; 24^{\circ} 18^{\prime} \mathrm{E}\right)$. The climate is cool and humid with a mean annual temperature of $3.9^{\circ} \mathrm{C}$; the coldest month is January and the warmest month is July with mean temperatures of $-6.9^{\circ} \mathrm{C}$ and $16.1^{\circ} \mathrm{C}$, respectively (Figure S-1). The effective temperature sum in this cool climate (sum of average daily air temperature over $5^{\circ} \mathrm{C}$ ) is $1275^{\circ} \mathrm{C}$, which occurs over a 169-day growing season; this ranged from 1046 to $1470^{\circ} \mathrm{C}$ showing no trend over the experimental period (Kokkonen and others $2019 \mathrm{a}, \mathrm{b})$. Mean annual precipitation is $689 \mathrm{~mm}$, a third of which falls as snow (Finnish Meterological Institute 2017). The experiment included three peatland types defined by a nutrient gradient (Table S-2): ombrotrophic bog, oligotrophic fen and mesotrophic fen, hereafter called bog, poor fen and rich fen, respectively. The rich fen was dominated by a dense cover of Carex lasiocarpa and herbaceous species, such as Menyanthes trifoliata. The ground layer was sparse and formed by Sphagnum and brown mosses. The poor fen was sparsely covered by C. lasiocarpa, below which was a dense layer of Sphagna. The bog had few dwarf shrubs, such as Empetrum nigrum and almost no herbaceous vegetation; a thick carpet of Sphagnum mosses covered the site. The experiment was established in 20002001 with an experimental WLD area on each peatland type accompanied by an undrained control area. After a calibration year, the WLD treatment was established by digging $30 \mathrm{~cm}$ deep ditches around the treatment areas. The WLD settings are explained in more detail in Kokkonen and others $(2019 a, b)$.

\section{Measurements}

We conducted a vegetation inventory in 2000/200 1 prior to the start of the treatment, and again in 2016 to describe the vegetation community on each site as impacted by WLD. Cover of each vascular plant and moss species was estimated on 40 circular permanent sample plots $\left(0.07 \mathrm{~m}^{2}\right.$ in size), located at $1.6 \mathrm{~m}$ intervals along transects across WLD and control areas on each site. The cover of each vascular plant species was estimated as a percentage of the total sample plot area; the sum of all species could be greater than $100 \%$ due to overlapping and layered vegetation. Transects were designed to cover the natural variation in vegetation communities across the site. Three closely related Sphagnum species ( $S$. angustifolium, $S$. flexuosum, and $S$. fallax) that were indistinguishable in the field and in many cases grew as a mixed community were recorded as Sphagnum recurvum complex. Since the study began prior to the division of S. magellanicum, we grouped S. medium and $S$. divinum as $S$. magellanicum (Hassel and others 2018); determining the species identity later was impossible as both species are known to habit the sites. The vegetation inventory is described in detail in Kokkonen and others (2019a, b).

To quantify photosynthetic potential for each site and treatment, we measured the photosynthetic light response curve of nine vascular plant species and nine moss species (Table 1; Figure S-12) that had high abundance at each site $\times$ treatment 


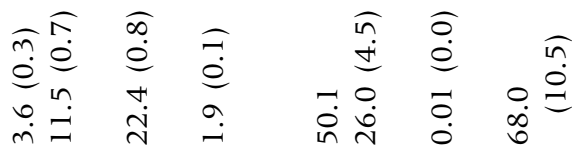

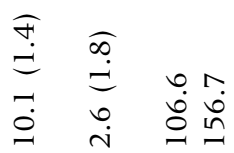

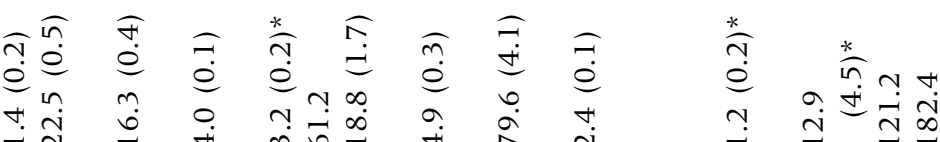

$\cong$

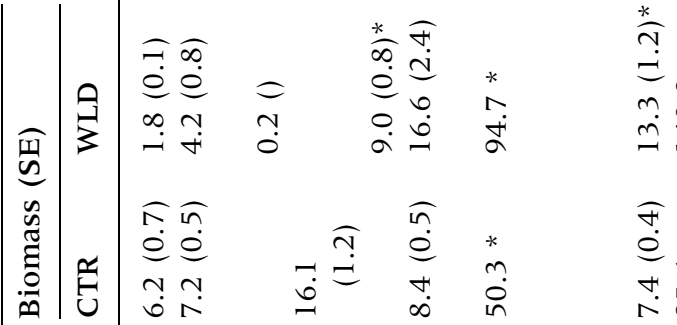

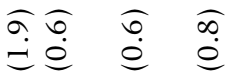

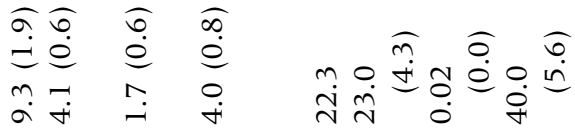

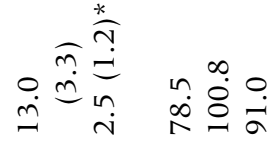

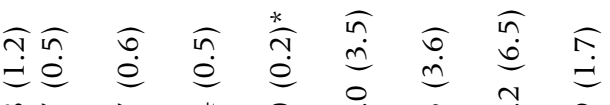

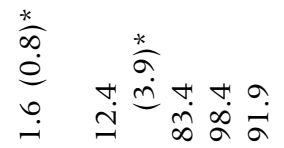

का क्ष

$\widehat{\mathrm{s}} \widehat{\infty} \quad \stackrel{*}{a} \quad \stackrel{*}{\hat{n}}$

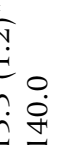

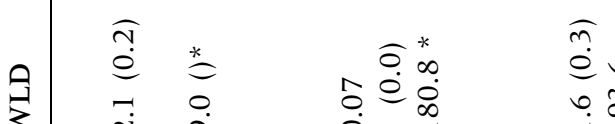

i $a$

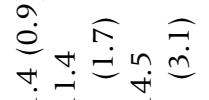

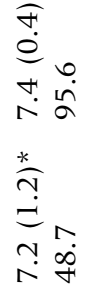

$\stackrel{\sim}{+} \hat{i}$

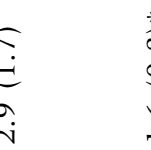

童衰这

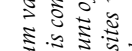

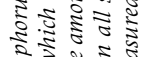

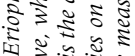

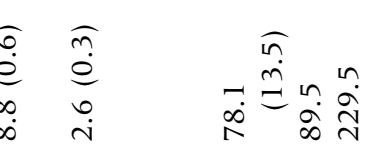

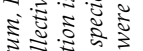

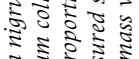

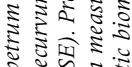

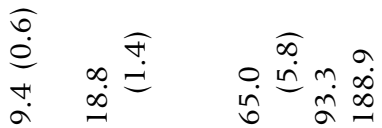

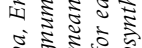

कू

ํำ

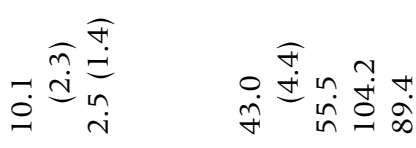

跣这

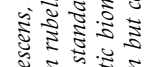

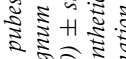

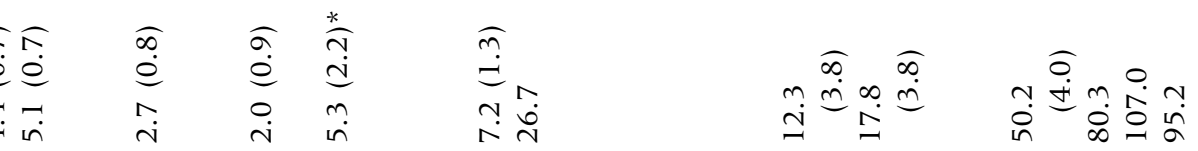

कृ

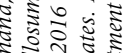

3.

政乐

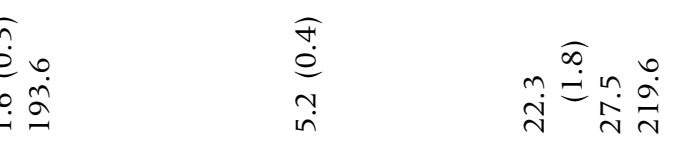

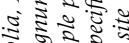

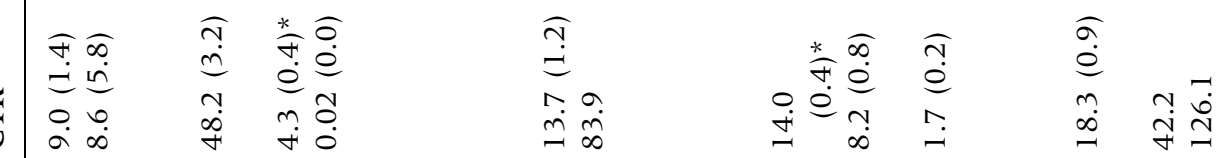

ฐँ ₹ิ

क्षे

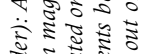

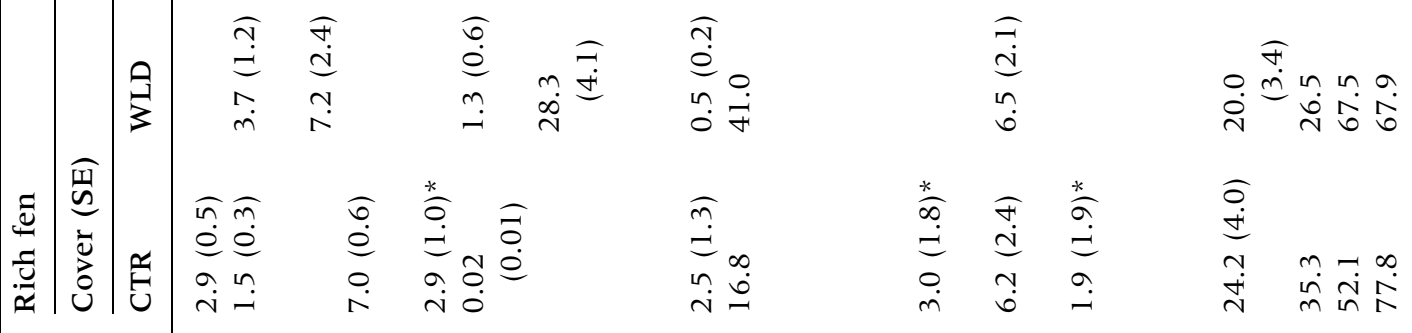

है 
combination, and species that were common in both WLD and control areas (Table 1). For photosynthesis measurements, we collected plant samples as peatland mesocosm blocks (approx. $30 \mathrm{~cm} \times 30 \mathrm{~cm} \times 40 \mathrm{~cm}$ ), which contained Sphagnum moss and at least one vascular plant species with its root systems. Studied plants were small in comparison with the size of the mesocosms so that the rooting system remained intact. The mesocosms were collected in the morning and were then transported to Hyytiälä Forestry Station $\left(61^{\circ} 50^{\prime} \mathrm{N}\right.$; $24^{\circ} 17^{\prime} \mathrm{E}$; ca. $5 \mathrm{~km}$ from Lakkasuo) where they were stored in a well-lit and ventilated location until they were measured within the same day. The mesocosms were stored in plastic containers to retain moisture and prevent further disturbance during transportation and storage. In addition, we occasionally collected mosses in smaller $(7 \mathrm{~cm} \times 7 \mathrm{~cm} \times 5 \mathrm{~cm})$ single-species samples. In case of trees (that is, Betula pubescens and Pinus sylvestris), measurements were made from a branch that was cut, immediately placed in a water container and stored for a maximum of $\mathrm{l} \mathrm{h}$ before the measurement. During the measurement, the transpiration rate was constantly monitored to ensure the physiological status of the plant was preserved. Each species $\times$ site $\times$ treatment combination contained between 3 and 7 replicates.

Two infrared gas analyzers were used for photosynthesis measurements: the LI-6400 Portable Photosynthesis System (Li-Cor Inc. USA) and the GFS-3000 Portable Gas-Exchange and Fluorescence System (Walz, Germany). For both systems, custom mesh-bottomed cuvettes $\left(6 \mathrm{~cm}^{3}\right.$ for Li-Cor and $8 \mathrm{~cm}^{3}$ for Walz) were made to accommodate the three-dimensional structure of Sphagnum mosses. Conditions within the cuvettes were set to be similar between the two devices: leaf temperature of $20^{\circ} \mathrm{C}$, carbon dioxide $\left(\mathrm{CO}_{2}\right)$ concentration at $400 \mathrm{ppm}$, flow rate at $500\left(\mu \mathrm{mol} \mathrm{\textrm {min } ^ { - }}\right.$ $\left.{ }^{1}\right)$, and impeller level at 5 . Relative humidity (rh) of the incoming air was set at $40 \%$ for vascular plants and at $60 \%$ for mosses, resulting in around $80 \%$ rh in the cuvette during sampling. In this way, mosses were able to retain moisture and photosynthesize, and the measurement devices were protected from excess moisture. Each sample was exposed to four light levels: $1500,250,35$, and $0 \mu \mathrm{mol} \mathrm{m} \mathrm{m}^{-2} \mathrm{~s}^{-1}$. Measurements began with the greatest light level, which was then changed to the next level after a constant photosynthesis rate was achieved. A single flux value at each light level was calculated by averaging the rate of change in $\mathrm{CO}_{2}$ concentration over a period when the value was stabilized.
For vascular plants, leaves were arranged in the cuvettes to maximize the leaf surface exposed to the light. After photosynthesis measurements, the area of leaves contained within the cuvette was carefully cut out and photographed for leaf area calculation. The fresh mass of these leaves was also recorded. Sphagnum moss samples were prepared by removing the moist capitula of Sphagna; all free water was removed by gently pressing the sample in absorptive paper. The capitula were then arranged into a cuvette at a similar density to that found in the field sampling area. All samples removed from cuvettes were oven-dried overnight at $40^{\circ} \mathrm{C}$ and their dry mass was recorded the following day. Data from each sample were checked for quality during the measurement and afterward; non-reasonable samples were discarded (for quality processing, see Supplementary Information S-3).

\section{Analysis}

\section{Vegetation Composition}

To measure the change in vegetation community over time, we calculated temporal beta-diversity index (TBI) values using the Bray-Curtis index for vascular plants and mosses for each sample plot at each site $\times$ treatment combination at two points in time: pre-treatment and 15/16 years later. The TBI describes the percentage difference between two time points (Legendre 2019; Legendre and Condit 2019). In our analyses, we used pre-WLD vegetation inventory data, inclusive of vascular plants and mosses, from 2000/2001 and inventory data from 2016. We used the TBI function in $\mathrm{R}$ package Adespatial to calculate TBI values, and we used a permutational paired t test to test whether the change in beta-diversity was significant between the two time points (Dray and others 2017). Plotlevel TBI values were tested using linear mixed effect models with site, treatment and their interaction as potential fixed factors and sample plot as the random variable (nlme v. 3.1-150 in R) using a marginal ANOVA to test whether the inclusion of each fixed predictor improved the model in comparison with the simpler model (Table S-4).

\section{Modeling Photosynthesis}

We applied nonlinear mixed-effects models to quantify the effects of WLD on photosynthetic light response parameters as impacted by site (Table S$5)$. Vascular plants and mosses differed strongly in their photosynthetic light response (marginal ANOVA $F$-test $p<0.001$ ), and these two groups were thus analyzed separately. Models were based on 
the hyperbolic light saturation curve (Smolander and Lappi 1985):

$$
A_{i j k l}=R_{i j k}+\frac{P_{\max _{i j k}} \operatorname{PPFD}_{i j k} l}{\alpha_{i j k}+\operatorname{PPFD}_{i j k} l}+e_{i j k l}
$$

where $A$ is observed net photosynthesis $\left(\mathrm{mg} \mathrm{CO}_{2}\right.$ $\mathrm{g}^{-1} \mathrm{~h}^{-1}$ ) at light level $l$, of sample $i$ from peatland $j$ and treatment $k . R$ is dark respiration $\left(\mathrm{mg} \mathrm{CO}_{2} \mathrm{~g}^{-}\right.$ ${ }^{1} \mathrm{~h}^{-1}$ ) and alpha $(\alpha)$ is the initial slope of the photosynthesis curve describing the ability to photosynthesize in low light. $P_{\max }$ is the calculated maximum photosynthesis $\left(\mathrm{mg} \mathrm{CO}_{2} \mathrm{~g}^{-1} \mathrm{~h}^{-1}\right)$ at full light saturation. PPFD is the photosynthetic photon flux density $\left(\mu \mathrm{mol} \mathrm{m}{ }^{-2} \mathrm{~s}^{-1}\right.$ ) (Smolander and Lappi 1985). Each parameter of this function $\left(P_{\max }, R, \alpha\right)$ was modeled separately (Mehtätalo and Lappi 2020).

Initially, all variables of interest (species, site, treatment, site $\times$ treatment) were included as fixed factors in the model with linear effects assumed. In addition, we included the device type used in measurements, and sampling date as fixed factors to account for their impact. Sample ID, which binds together the successive measurements under the different light levels, was the only random variable. In general, non-significant variables $(p>0.05)$ based on $f$-tests were then removed. Regardless of significance, we retained the effect of device to account for any unwanted variation and species, which is a logical source of variation, but could have been non-significant due to the low replicate number. In the vascular plant models, the residual error $\left(e_{i j k l}\right)$ was normally distributed with mean zero and constant variance (Table S-6A). In the moss models, the variance of $e_{i j k l}$ was modeled using an exponential variance function with PPFD as the predictor (Table S-6B).

To focus on the direct response of photosynthesis to WLD and to analyze functional adaptation within a species, we selected four species considered to be generalist species: Andromeda polifolia, Eriophorum vaginatum, Pinus sylvestris, and S. magellanicum (Table 1) and parameterized new models separately for each species. The effects of peatland type and WLD treatment on the photosynthetic light response parameters were tested as described above.

\section{Photosynthetic Biomass}

Photosynthetic biomass $\left(\mathrm{g} \mathrm{m}^{-2}\right.$; Figure la) was calculated for field layer vascular plants using leaf area index $\left(\mathrm{LAI}, \mathrm{m}^{2} / \mathrm{m}^{2}\right.$ ) values measured in 2017 at the peak of the growing season (early July) on eight (rich fen) or nine (poor fen and bog)
$60 \times 60 \mathrm{~cm}$ sample plots on each treatment area. For each plot, the number of leaves of each species was counted. We then collected a minimum of ten comparable leaves from treatment areas adjacent to the plots and measured the green leaf area of these using a leaf scanner (Licor LI-3000). To obtain the LAI for each site, individual leaf area was multiplied by the number of leaves on the fixed-area plot, resulting in species-specific leaf area per unit area. Species-specific LAI was multiplied by the specific leaf area $\left(\mathrm{g} / \mathrm{m}^{2}\right.$ leaf area) calculated from our photosynthesis sample material, which provided a species-specific photosynthetic biomass (g/ $\mathrm{m}^{2}$ peatland surface; Figure la) estimate for each species. For trees, the photosynthetic biomass (Figure $1 b$ ) was calculated based on tree height, diameter, and density from the tree stand survey completed in 2017 using circular fixed-radius plots located on a systematic $10 \mathrm{~m} \times 10 \mathrm{~m}$ grid on each treatment area. Leaf area for trees greater than $1 \mathrm{~m}$ in height was calculated using the functions in Repola $(2008,2009)$, and saplings less than $1 \mathrm{~m}$ tall were calculated using previously described LAI measurements. For mosses, photosynthetic biomass (Figure 1c) was calculated using species-specific capitulum dry mass (g/capitulum) measured during photosynthetic measurements, cover values $\left(\mathrm{m}^{2} /\right.$ $\mathrm{m}^{2}$ ) estimated in the 2016 vegetation survey, and capitulum density in the moss carpet (number of capitula $/ \mathrm{cm}^{2}$ ) measured in 2016 by counting the number of capitula in a fixed area occupied only by the target species in field conditions.

\section{Upscaling Leaf-Level Photosynthesis}

To assess the impact of WLD on moss and vascular plant site-level photosynthesis, we upscaled the leaf-level measurements using estimated photosynthetic parameters to a site-level net photosynthesis estimate for the month of July 2016 based on photosynthetic biomass (Figure $1 \mathrm{~d}-\mathrm{h}$ ). Due to the significant effect of date for moss $P_{\max }$ over the measurement period, daily estimates of $P_{\max }, \alpha$, and $R$ were calculated for July for each site $\times$ species $\times$ treatment combination by applying previously derived models (Table S-6) of these parameters (for example, Table S-10; Figure 1d). Leaf-level hourly net photosynthesis $(A)$ per dry gram of photosynthetic biomass $\left(\mathrm{mg} \mathrm{C} \mathrm{h}^{-1} \mathrm{~g}^{-1}\right.$; Figure $1 \mathrm{e}$ ) is then calculated using equation 1 , into which was inputted the estimated daily photosynthetic response curve parameters and the July 2016 hourly PPFD values from Hyytiälä Research Station. Finally, A was multiplied by species-specific photosynthetic biomass $\left(\mathrm{g} \mathrm{m}^{-2}\right.$; Figure lf) of each 


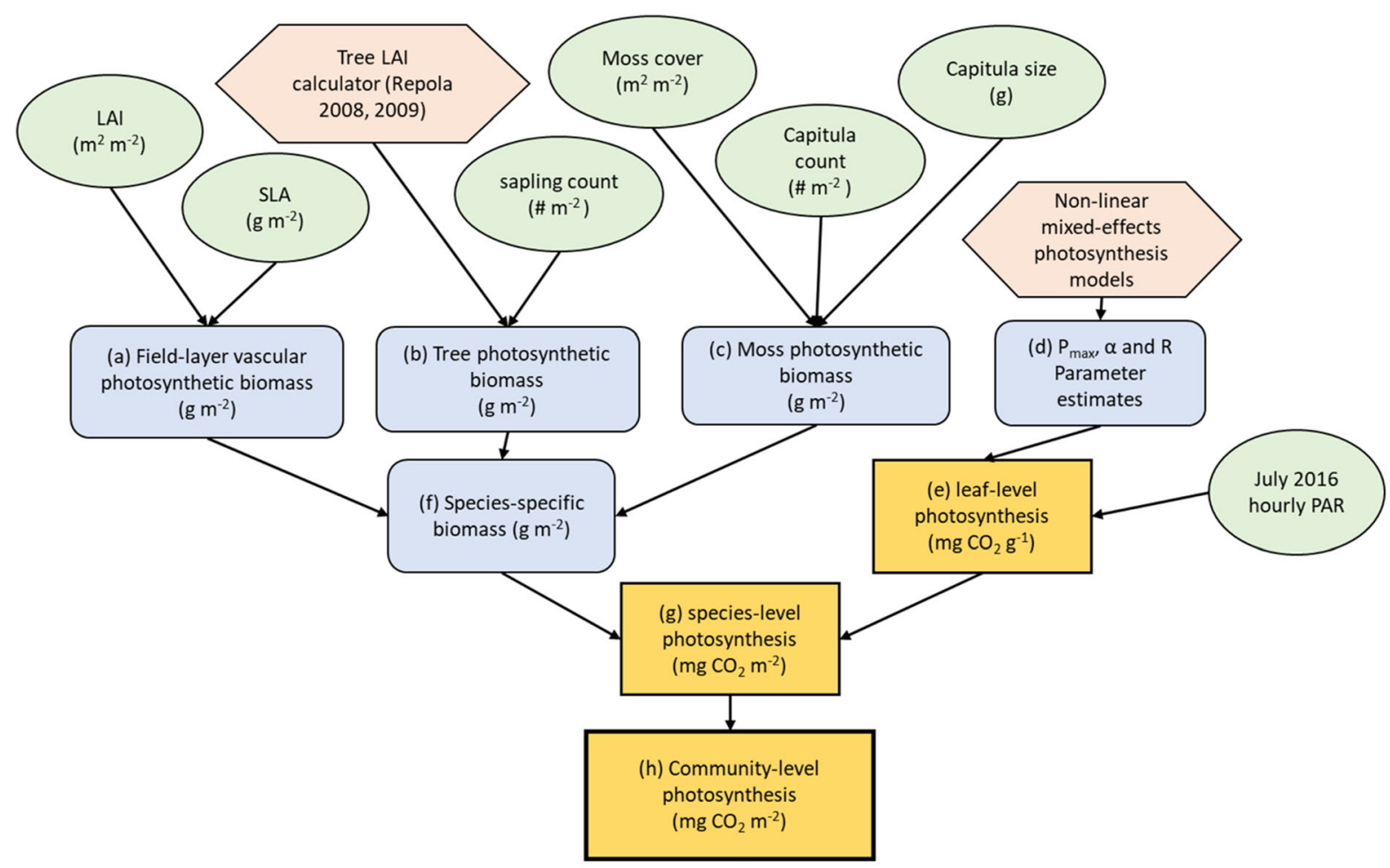

Figure 1. Upscaling process flow chart. Field data (ovals) was combined with model information (polygons) to calculate species biomass and parameter estimates (blue rectangles, calculation process). Species photosynthesis was calculated for the leaf-level and species-level, which was upscaled to community-level leaf photosynthesis (yellow rectangles, main results).

site $\times$ treatment to give area-based hourly net photosynthesis $\left(\mathrm{mg} \mathrm{C} \mathrm{h}^{-1} \mathrm{~m}^{-2}\right.$; Figure $\left.\mathrm{lg}\right)$. Finally, these were summarized by site to give a monthly value (Figure $1 \mathrm{~h}$ ).

To ensure that the upscaled values were as accurate as possible, we included all possible species for which we had photosynthesis measurements and were able to estimate biomass values (Table 1). In cases where the photosynthesis estimates were not available for a species on a given site $\times$ treatment combination, parameter values were estimated using mean values for that species from the most ecologically similar (that is, hydrology and plant community) site $\times$ treatment combination where measurements were carried out for that species (Table S-8). Parameter estimates used in upscaling are reported in Supplementary Table S-9.

\section{Results}

Water Table

Before ditching, the water table was approximately 5,20 and $10 \mathrm{~cm}$ below the moss surface on the rich fen, poor fen and bog, respectively. Initially, ditching in 2001 (bog, rich fen)/2002 (poor fen) caused the largest water table drop in the rich fen and smallest drop in the bog (Figure 2), with the decrease in water table ranging between 15 and $20 \mathrm{~cm}$ in all WLD areas. With time, the effect of WLD became smaller, and in 2017, the water table was on average about $7 \mathrm{~cm}$ lower in the WLD areas than in the control (Figure 2). Furthermore, we observed a temporal trend in the water table in the control area of the rich fen site, where the water table decreased for about $7 \mathrm{~cm}$ between years 2000 and 2017.

\section{Effect of WLD on Vegetation Composition}

Over the study period from 2001 to 2016, vascular plant and moss communities of all control and WLD sites underwent some species turnover, yet the changes were larger under the WLD treatment with 5-15 cm drop in water table (Figure 3, Table S-4). The TBI values for vascular plants were significantly greater on the rich fen and poor fen WLD sites compared to controls (Figure 3A), with the rich fen WLD exhibiting the greatest change (Figure 3A). The changes in the vascular plant community after WLD were a mix of diversity losses and gains (Table 2; Table S-10). For mosses, 


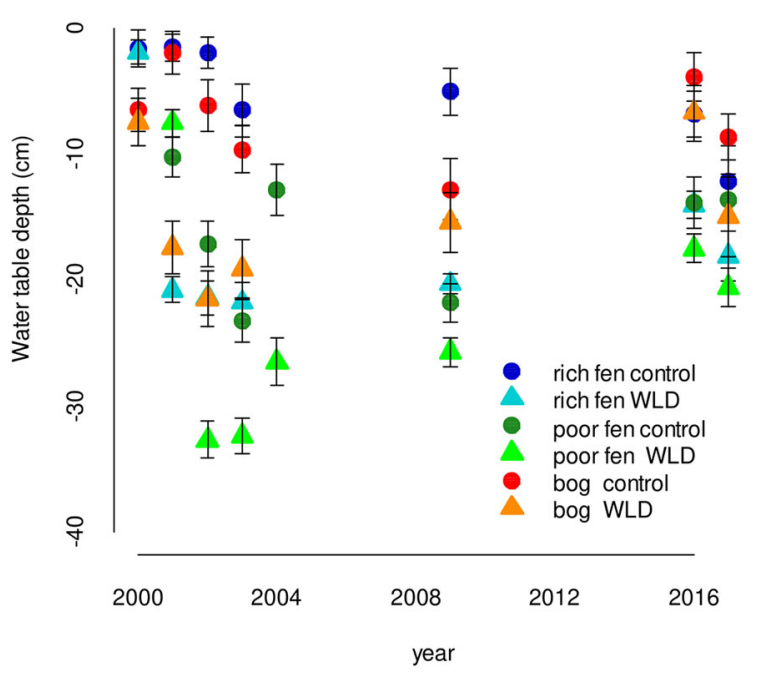

Figure 2. Water table in relation to the moss surface measured from perforated water wells on experimental sites over the duration of the experiment. Measurements were performed in 2000, 2001, 2002, 2003, 2004, 2009, 2016, and 2017. Each treatment area had eight to nine water wells distributed over the site, from which water table depth was recorded on at least a monthly basis between May and September. Average and standard error for each treatment area across all wells are shown.
WLD induced significantly greater TBI values on all sites (Figure 3B), with changes dominated by diversity losses on all WLD sites, significantly so on the poor fen (Table 2; Table S-10).

The vegetation change on the rich fen site was characterized by a shift in the dominant vegetation from sedges (C. lasiocarpa) to woody plants $(P$. sylvestris, Betula pubescens and B. nana) (Table 1). On the poor fen, dominance switched from $C$. lasiocarpa to $E$. vaginatum, B. nana and $P$. sylvestris (Table 1 ). There were no clear changes in bog vascular plant cover following WLD (Tables 1 and 2). For mosses, the rich fen lost flark- and hummock-adapted species in favor of lawn species, such as Sphagnum recurvum collective and $S$. magellanicum (Table 1). The cover of $S$. papillosum was reduced on the poor fen following WLD (Table 1). In the bog site, the cover of hollow species $S$. cuspidatum decreased, while the cover of low lawn species $S$. balticum and S. rubellum increased (Table 1).

The four generalist plant species, that is, $A$. polifolia, E. vaginatum, P. sylvestris and S. magellanicum were found across nearly all sites with varying abundance (Table 1). A. polifolia and S. magellanicum tended to have greater cover and biomass on

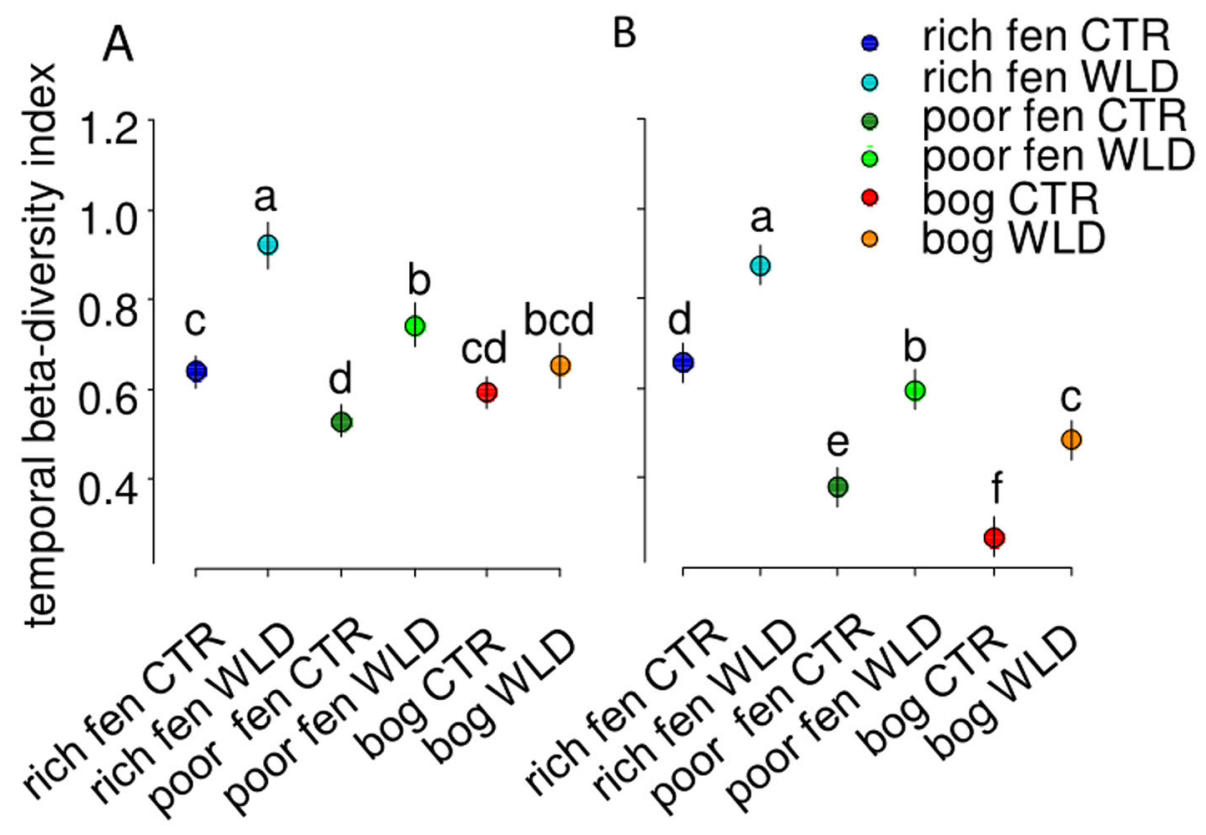

Figure 3. Effects of site (rich fen, poor fen, bog) and treatment (control, CTR, or water level drawdown, WLD) on temporal beta-diversity index (TBI) values as found using linear mixed-effects models for $\mathbf{A}$ vascular plants and $\mathbf{B}$ mosses. Greater index values indicate larger changes in plant diversity between pre-treatment measurements and 15/16 years later. Significance $(p<0.05)$ found using linear mixed-effects models marginal ANOVA tests is indicated using lettering (a-f) for comparisons within site and treatment types. Full model results are shown in Table S-3. 
Table 2. Mean Temporal Beta-diversity Index (TBI) Values for Vascular Plants and Mosses on Each Site $\times$ Treatment Combination.

\begin{tabular}{|c|c|c|c|c|}
\hline \multirow[t]{2}{*}{ Site } & \multicolumn{2}{|c|}{ Vascular plants } & \multicolumn{2}{|l|}{ Mosses } \\
\hline & CTR & WLD & CTR & WLD \\
\hline Rich fen & $0.639(-)$ & $0.921(+)$ & $0.686(-)$ & $0.844(-)$ \\
\hline Poor fen & $0.528(+)$ & $0.744(+)$ & $0.341(-)$ & $0.635(-)$ \\
\hline Bog & $0.594(-)$ & $0.654(-)$ & $0.278(-)$ & $0.474(-)$ \\
\hline
\end{tabular}

$(+)$ or (-) indicates whether changes in diversity were net gains or losses, respectively, and bold type indicates statistically significant $(p<0.05)$ changes from permutational $t$ tests. Larger TBI values indicate greater differences in plant community between the two measurement times.

control sites, whereas E. vaginatum seemed to benefit from some level of WLD on the poorer peatland types by increasing cover and/or biomass (Table 1). Cover and biomass of $P$. sylvestris increased in response to WLD in both fens but remained the same in the bog (Table 1).

\section{Effect of WLD on Photosynthetic Light Response Parameters as Impacted by Site}

The WLD treatment significantly affected all vascular plant photosynthetic light response parameters $\left(P_{\max }, \alpha, R\right)$, as well as moss $P_{\max }$ and $\alpha$ (Figure 4, Table S-6). The WLD treatment significantly increased vascular plant $P_{\max }$ on all sites (Figure 4A, Table S-6). Site also had a significant impact on $P_{\max }$ in the WLD areas, where the rich fen exhibited the greatest $P_{\max }$ values and the bog the lowest values (Figure 4A, Table S-6A). In the rich fen, the initial slope of vascular plant photosynthesis, $\alpha$, was significantly greater on the WLD treatment compared to the control, where it was also significantly greater than on both other sites (Figure 4C, Table S-6A). Likewise, vascular plant $R$ was significantly greater on the WLD treatment, while site did not affect the $R$ value (Figure $4 \mathrm{E}$, Table S-6A). Moss $P_{\max }$ was significantly greater on the poor fen WLD treatment than in any of the other site/treatment areas (Figure 4B, Table S-6B). The WLD treatment significantly increased moss $\alpha$ on all sites (Figure 4D). The WLD treatment did not affect moss $R$, but it was significantly greater on the poor fen than on the other sites (Figure 4F, Table S-6B).

\section{Effect of WLD on Photosynthetic Light Response Parameters as Impacted by Species}

Species identity had a significant impact on all vascular plant light response parameters but not on moss parameters (Table S-6, Figure S-7). Of the vascular plants, the greatest $\alpha, P_{\max }$ and $R$ values were found from the same species, that is, $R$. chamaemorus and B. pubescens (Table S-6). Similarly, the lowest parameters were found from the same species, that is, P. sylvestris and C. lasiocarpa (Table S6). As a result of patterns in light response parameters, leaf-level photosynthesis for an average 24-h period in July showed a greater range within vascular plant species than moss species (Figure 5, Table S-9).

In the models built separately for the selected four generalist species, WLD did not significantly affect any of their parameters $\left(P_{\max }\right.$, alpha and $R$ ). However, in these models for generalist species, most parameters tended to be greater in WLD areas compared to control areas (Figure 6, Table S-11). Leaf-level photosynthesis revealed differences between sites and treatments, as demonstrated by the generalist vascular species that were present at multiple sites and treatments: The rich fen WLD exhibited the greatest photosynthetic rates, while the rich fen control, bog WLD and bog control areas had the lowest (Figure 6A-C). Poor fen was intermediate for these species, with WLD areas displaying greater upscaled photosynthesis than control areas (Figure 6A-C). The differences in the generalist moss species $S$. magellanicum leaf-level photosynthesis across areas were small, but contrary to vascular plant generalists, the greatest rates were found at WLD poor fen areas and least in control and bog areas (Figure 6D). This pattern for leaf-level photosynthesis of generalist species was lost when the biomass differences between species were accounted for (Figure 6E-G): For species-level photosynthesis, plant biomass determined overall photosynthesis.

\section{Site-Level Photosynthesis}

Upscaled site-level photosynthesis was similar on the control areas across the different sites, yet the contribution of vascular plants and mosses strongly 

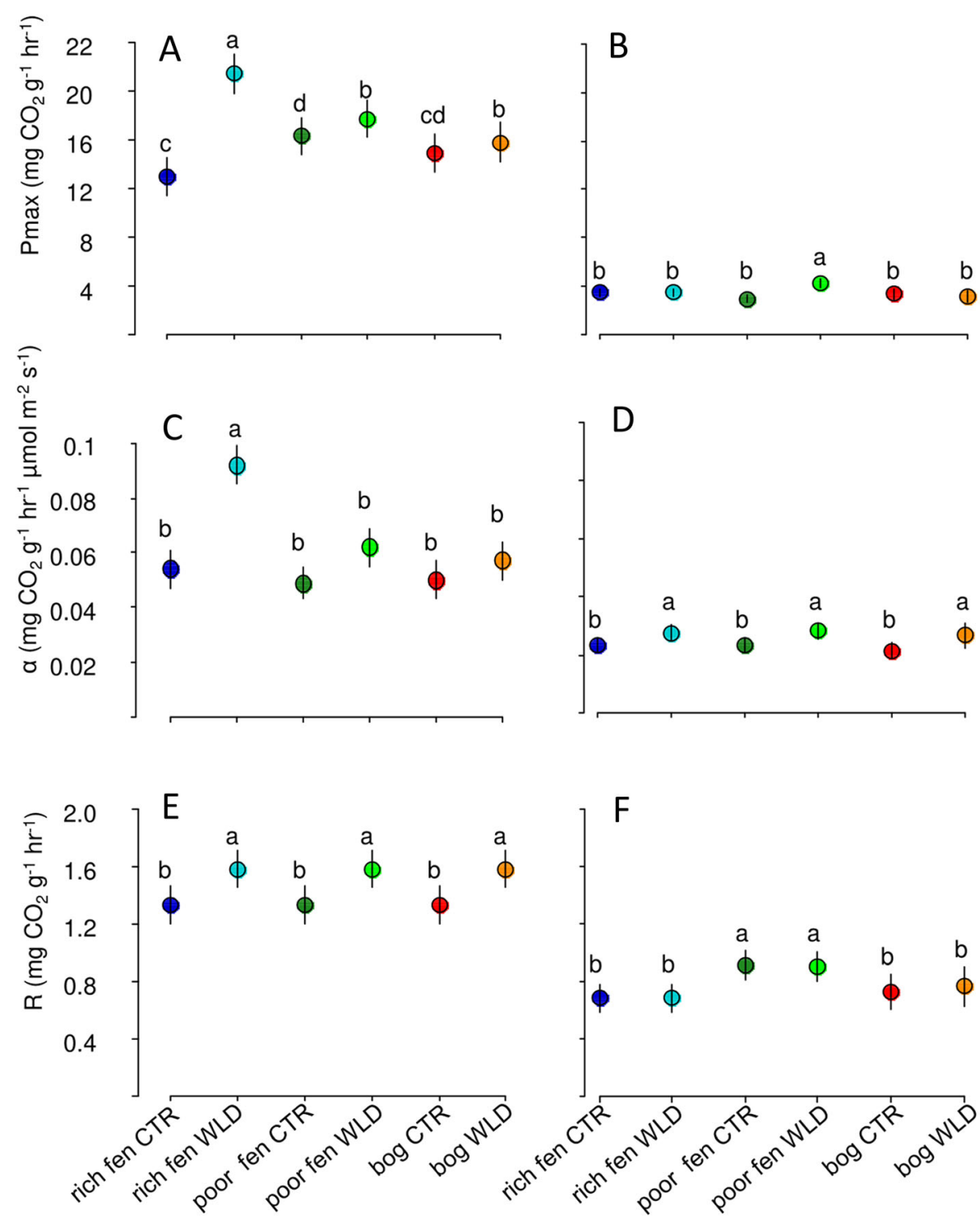

Figure 4. Effects of site (rich fen, poor fen, bog) and treatment (control, CTR, or water level drawdown, WLD) on photosynthetic response parameters, maximum photosynthesis $\left(P_{\max }, \mathbf{A}\right.$ and $\left.\mathbf{B}\right)$, alpha $(\alpha, \mathbf{C}$ and $\mathbf{D})$, and respiration $(R, \mathbf{E}$ and $\mathbf{F}$ ), from nonlinear mixed-effects models. Alpha is the initial slope of the photosynthetic response curve (mg $\mathrm{CO}_{2} \mathrm{~g}^{-}$ ${ }^{1} \mathrm{~h}^{-1} \mu$ mol photons $\left.\mathrm{m}^{-2} \mathrm{~s}^{-1}\right), P_{\max }$ is the calculated maximum photosynthesis $\left(\mathrm{mg} \mathrm{CO}_{2} \mathrm{~g}^{-1} \mathrm{~h}^{-1}\right)$, and respiration is $\mathrm{CO}_{2}$ flux in the dark $\left(R, \mathrm{mg} \mathrm{CO} \mathrm{g}^{-1} \mathrm{~h}^{-1}\right)$. Significant effects $(p<0.05)$ found from marginal ANOVA testing are indicated with lettering $(\mathrm{a}-\mathrm{d})$ for comparisons within site and treatment type. Panels $\mathbf{A}, \mathbf{C}$ and $\mathbf{E}$ show differences among sub-sites for Eriophorum vaginatum as a representative of vascular plants (the only species present on all sub-sites) and panels B, D, and $\mathbf{F}$ show the mean of all moss species (species was not a significant predictor for moss photosynthesis). Estimates are from the Licor infrared gas analyzer and the date is 1 July (where included in the model). Full model results are shown in Table S-5.

varied between the sites (Figure 7). The contribution of vascular plants increased with increasing nutrient status (Figure 7A), while mosses increased with decreasing nutrient status, being highest at the bog site (Figure 7B). However, there were large differences between the WLD treatments across the sites caused by the changes in vascular plant pho- tosynthesis (Figure 7A). The rich fen displayed the greatest photosynthesis on the WLD treatment and the largest difference between the treatments (Figure 7). The poor fen also showed greater photosynthesis in the WLD area than in the control area, while photosynthesis in the bog was slightly lower in the WLD area. Our results highlight the 

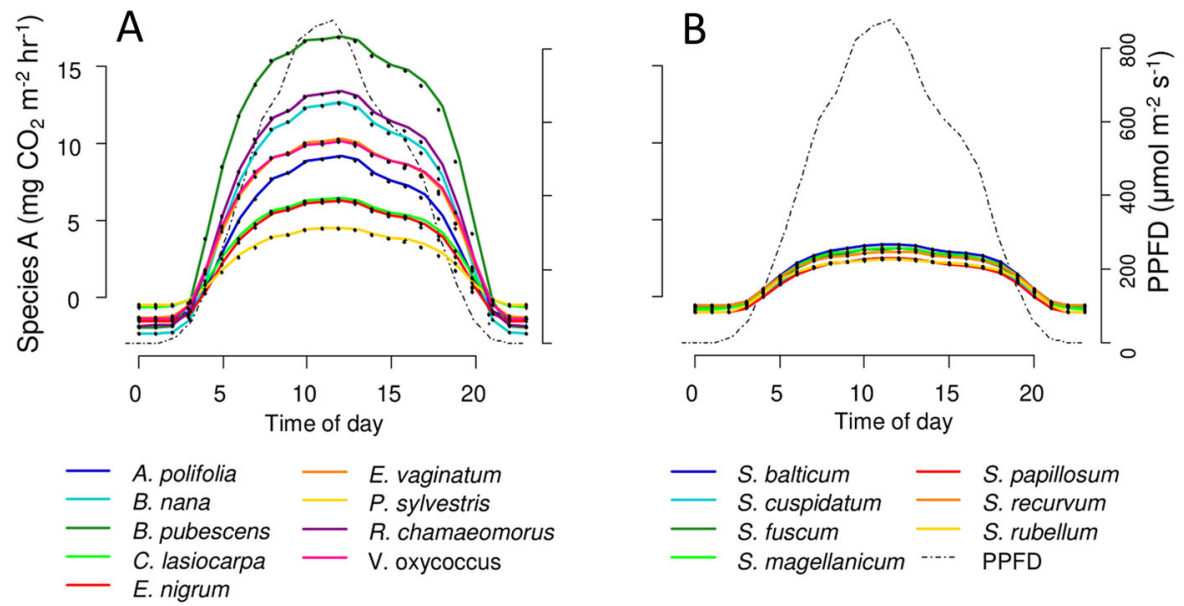

Figure 5. Average hourly net photosynthesis $\left(\mathbf{A} \mathrm{mg} \mathrm{CO}_{2} \mathrm{~g}^{-1} \mathrm{~h}^{-1}\right)$ across an average day in July 2016 with values for species averaged across all treatment areas. Photosynthetic photon flux density (PPFD) is taken as the mean PPFD for a given hour. Time of day is shown using 24-h notation. Vascular plants are shown in (A) and mosses in (B).
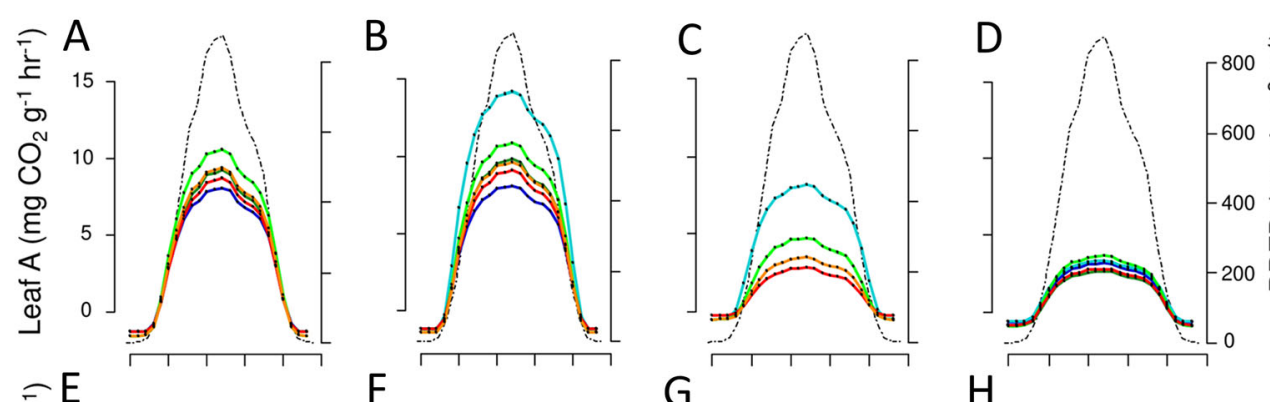

in
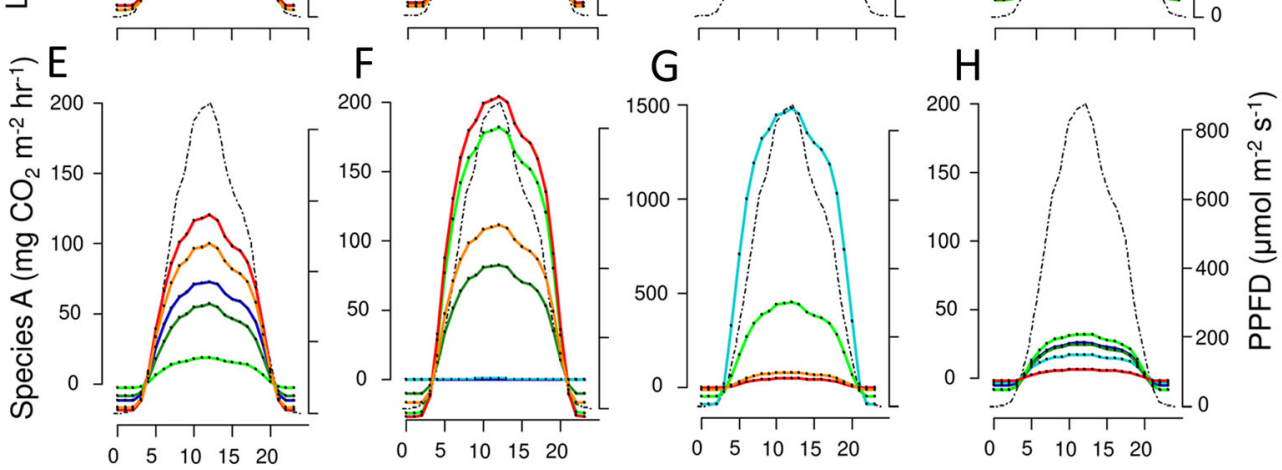

rich fen ctr rich fen WLD poor fen ctr poor fen WLD bog ctr bog WLD

Figure 6. Average hourly photosynthesis (A) per gram of photosynthetic biomass and net primary productivity (NPP) per square metre of peatland by site/treatment combination for four selected generalist species: A and $\mathbf{E}$ Andromeda polifolia, B and $\mathbf{F}$ Eriophorum vaginatum, $\mathbf{C}$ and $\mathbf{G}$ Pinus sylvestris and $\mathbf{D}$ and $\mathbf{H}$ Sphagnum magellanicum. Photosynthetic photon flux density (PPFD) is taken as the mean PPFD for a given hour of all days in July. Time of day is shown using 24-h notation. Note that the scale for $P$. sylvestris NPP $(\mathbf{F})$ differs from the others.

impact that a single species can have on site-level photosynthesis: On the rich fen, P. sylvestris became the most dominant species after WLD (Table 1) and its photosynthesis rate was greatest in this community (Figure 6C) making it the single greatest contributor to photosynthesis increase following WLD on the rich fen.

\section{Discussion}

In this study, as hypothesized, the long-term WLD impacted peatland photosynthesis through two mechanisms-species turnover and changing photosynthetic capacity. The magnitude of these two mechanisms changed parallelly across the studied peatland site types, so that the largest overall change in photosynthesis occurred in the rich fen 


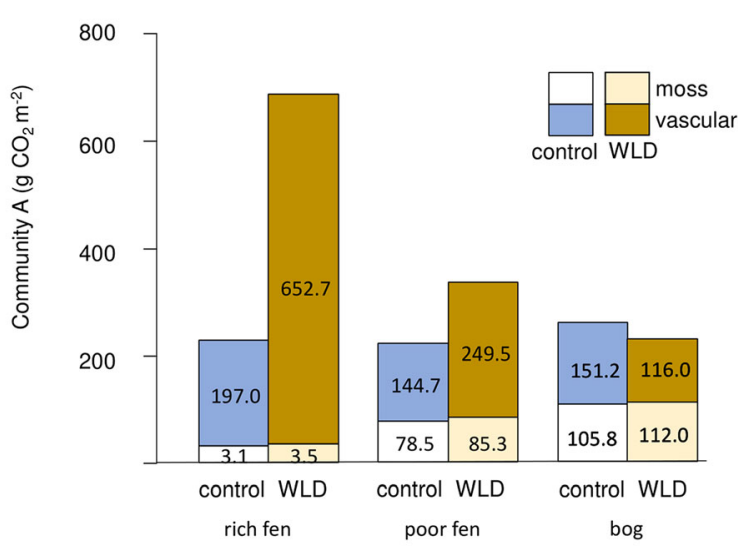

Figure 7. Cumulative community-level photosynthesis for vascular plants and mosses by site for both control and water-level drawdown (WLD) treatments as the sum of all species and all days in July. The value for each community-level estimate is indicated within the bar for that plant type and site.

that had both the greatest species turnover and the most noticeable change in photosynthetic capacity. On fen sites, we observed increased photosynthesis following WLD, while there was a slight decrease in the bog. The increase in the fen sites was driven by vascular plants as both the dominance of the more productive species and the photosynthetic capacity (quantified by $P_{\max }$ ) increased.

Community composition significantly changed after WLD (see also Kokkonen and others 2019a, b), but the change was not equal at all sites. As hypothesized, the rich fen underwent the strongest species turnover toward an arboreal system, while the vegetation composition in the bog was the most stable of the three peatland types. Typically, WLD changes the growth substrate of vascular plants by increasing the depth of aerated peat (Chivers and others 2009; Flanagan and Syed 2011; Strack and Waddington 2007; Straková and others 2012; Waddington and others 2015), while the moss growing environment changes primarily due to reduced surface moisture (Dimitrov and others 2011). Drier conditions reduce the cover of specialist species adapted to inundated environments as they are more prone to drought stress and invest energy in structural adaptations that are no longer advantageous in drier conditions (Rydin and Jeglum 2013). A lowered water table allows peatland generalist and forest-adapted species to invade the newly available growing space and utilize it to their advantage (Hájek and others 2009; Kokkonen and others 2019a, b; Laine and others 1995; Munir and others 2014; Strack and others 2006).
Following WLD, aerobic decomposition releases nutrients that were previously stored in the anaerobic peat $(\mathrm{Bu}$ and others 2011; Munir and others 2017; Straková and others 2012). Indeed, nutrient availability is one of the key reasons why peatland types respond differently to WLD (Westman and Laiho 2003). The direction and rate of change in a peatland depend on whether WLD removes the most restricting resource limitation of the growth occurring at the particular site, as is stated by the Liebig's Law of the Minimum (Ågren and others 2012). On rich fens, nutrient availability is generally sufficient so that the high-water table is the main growth-limiting factor prior to WLD. Therefore, a lowered water table leads to rapid colonization of the newly available growing space (Davis and others 2000) and greater photosynthesizing biomass. Bogs, on the other hand, are nutrient-limited environments (Westman and Laiho 2003) and the available minerals are insufficient for productive species, particularly vascular plants. Therefore, in bogs, nutrient availability, not a high WT, is the main growth-limiting factor and the impact of WLD is less than in the fens.

Previous studies have shown that WLD has an initial negative impact on moss cover (Riutta and others 2007; Strack and others 2006) and correspondingly we observed significant long-term losses of Sphagnum species, especially those specialized to inundated conditions (for example $S$. cuspidatum) in our sample plots. Despite this loss, certain bog specialists, such as S. fuscum in this study, may persist after WLD as they can withstand nutrientpoor conditions, occasional droughts and exposure (Laine and others 2015; Rydin and Jeglum 2013). Also in the rich fen, some Sphagnum species (including S. magellanicum and S. recurvum collective) persisted after WLD even after the site had become dominated by vascular plants. The denser vascular plant canopy likely aids the survival of these mosses by reducing exposure and the vapor pressure deficit below the plant canopy (Hájek and others 2009; Kangas and others 2014; Minkkinen and others 1999; Rannik and others 2013), while still allowing sufficient light through the canopy and not overwhelming the mosses with leaf litter. In addition, some Sphagnum species have been found to have considerable trait plasticity (Jassey and Signarbieux 2019) making them generalists able to persist in a range of conditions (Bengtsson and others 2021) such as Sphagnum magellanicum in our study.

To our knowledge, the direct effect of WLD on photosynthesis rate of peatland vascular plants has been studied only in Laine and others (2016) 
where no impact was observed after long-term forestry drainage. In this study, more moderate long-term WLD increased the photosynthesis rate of vascular plants at all nutrient levels, while mosses were unaffected. Similar results with Sphagna have been reported by Kangas and others (2014) and Hajek and others (2009) where longterm drainage did not change the photosynthesis rate. In the ecosystem scale, short-term drought situations have generally been reported to decrease photosynthesis (Adkinson and others 2011; Aurela and others 2007; Cai and others 2010; Leppälä and others 2011; Peichl and others 2014; Rinne and others 2020a, b; see however, Flanagan and Syed 2011). This decrease was also found in many North American studies with initially deeper water tables (Chimner and others 2017; Chivers and others 2009; Munir and others 2014, 2015; Whittington and Price 2006). However, in this study, the moderate, long-term WLD was found to increase ecosystem-level photosynthesis, but this effect was dependent on peatland type. We observed the highest increase in photosynthesis following WLD in the rich fen, smaller increase in the poor fen and nearly no impact in the bog. This is a reasonable finding since site trophic level has been shown to impact photosynthesis as plants require sufficient nutrients to support increased photosynthesis and subsequent growth (Lloyd and Farquhar 1996; Ågren and others 2012; Fatichi and others 2014; Eskelinen and Harrison 2015). In addition, the vascular plant species turnover toward more productive species on WLD areas played a major role in the observed increases in $P_{\max }$ as previously observed by Flanagan and Syed (2011) and Munir and others (2015). This contrasts with short-term droughts where species turnover is not possible and water-limited conditions directly restrict peatland photosynthesis (Rinne and others 2020a, b). Overall, following WLD, the increases in plant cover on wet surfaces, that are typical features of fens, can also increase site-level photosynthesis (Strack and others 2006; Strack and Waddington 2007; Laine and others 2019). In addition to the increased photosynthetic capacity, WLD and the associated dominance of arboreal vascular plants had supported adaptation to altered light conditions under the shading of higher plants. This was seen in the increased parameter $\alpha$ that defines the initial slope of the light response curve (Loach 1967; Friend 1984; Hájek and others 2009). The greater rates of leaf respiration following WLD in all peatland types agree with findings of ecosystem level studies (Strack and others 2006; Strack and Waddington 2007; Chivers and others
2009; Laine and others 2009, 2019; Churchill and others 2015). However, in those, increased respiration is generally linked to increased decomposition, while in our species-level study, the role of greater rates of overall plant metabolism was possible to assess.

The photosynthesis measurements in this study carry the potential error caused by the relocation of plants from the field to the laboratory. However, we surmise this error source as negligible since previous studies (Laine and others 2016; Kangas and others 2014; Korrensalo and others 2016) have successfully used a similar approach and reported photosynthesis levels that are in the same range to other studies on peatland vascular plants (Grace and Woolhouse 1970; Small 1972) and Sphagnum mosses (Rydin and McDonald 1985; Schipperges and Rydin 1998; Harley and others 1989; Gerdol and others 1996; Hájek and others 2009; Granath and others 2009; Kangas and others 2014; Bengtsson and others 2016; Korrensalo and others 2016; Laine and others 2016) and comparable to the ecosystem-scale GPP measured in the field with an eddy covariance tower (Korrensalo and others 2017). Another potential error source affecting the response of vegetation is the differential effect of the WLD treatment at the three sites. However, the difference in the magnitude of WLD effect decreased over time and was negligible in the year when the measurements of this study were made. In addition, we observed a decrease in the water table at the control area of the rich fen site, which may have affected the nutrient availability in that site independent of the WLD treatment.

Our results suggest that vascular plants are the key group that drive changes in photosynthesis following moderate WLD, whereas mosses support stability. Firstly, unlike for vascular species, the photosynthetic parameters did not vary among the moss species, indicating that species turnover within Sphagna would have a minor impact on the moss community photosynthesis. Secondly, the photosynthesis of vascular plants increased after WLD more than that of mosses. Vascular plants are well-suited to benefit from drier conditions because their root systems are able to transport water and nutrients from deeper sources, making them less reliant than mosses on surface water availability (Dimitrov and others 2011). Lastly, the important difference between vascular plants and mosses is simply their potential to increase photosynthesizing biomass after WLD as vascular plants are not limited to a single layer like mosses. Although moss biomass can increase after WLD, like in the poor fen studied here, it is limited by the growth habit of 
mosses, while vascular plant biomass at both studied fen sites doubled after the invasion of highgrowing shrubs and trees.

We have shown that with adequate nutrient availability, WLD has the potential to increase the photosynthesis of boreal peatlands. In previous studies, WLD has rather consistently resulted in increased ecosystem respiration and decreased methane emissions, while the reported estimates of photosynthesis in the literature are extremely variable (Ballantyne and other 2014; Chivers and others 2009; Laine and others 2009, 2019; Munir and others 2014, 2015; Oechel and others 1998; Peltoniemi and others 2016; Riutta and others 2007; Strack and Waddington 2007). Our results imply that the interaction between vegetation community and nutrient availability can explain the observed variable response of peatland photosynthesis to WLD. The difference between vascular plant and moss responses to WLD was visible at the site-level in this study so that the less vascular species turnover the site undergoes, the less likely an overall site-level change in photosynthesis becomes. Vascular plants, in turn, responded to WLD more readily at minerotrophic fens than nutrientlimited bogs, which agrees with the general understanding across ecosystems (Davis and others 2000; Eskelinen and Harrison 2015; Roberts and Gilliam 1995). Rich fens are the most sensitive to WLD as they are clearly dominated by vascular plants and because nutrient availability is sufficiently elevated to support the invasion of highly productive vascular plant species once the growthlimiting water table is lowered (Minkkinen and others 1999). Poor fens, co-dominated by vascular plants and Sphagnum mosses, undergo changes to a lesser extent, while Sphagnum moss-dominated bogs retain their functions. This is in agreement with other studies that have found bogs to be resistant to change and fens to be sensitive, with the latter often increasing productivity after WLD (Minkkinen and others 1999; Weltzin and others 2000; Talbot and others 2014; Laine and others 2021). However, with more extreme drainage, bog species composition and productivity may also be impacted (Westman and Laiho 2003; Heijmans and others 2008; Harris and others 2020; Evans and others 2021). Therefore, the response of photosynthesis to WLD is likely to be further complicated by the depth of WLD and by pre-existing hydrological conditions.

\section{ACKNOWLEDGEMENTS}

The authors would like to thank Jinnan Gong for his help in data collection and processing and Hui Zhang for her valuable comments to an earlier version of the manuscript. Funding was provided by the Academy of Finland (projects 287039 and 330840 ) and the Kone Foundation. We are grateful for Academy of Finland Flagship Programme " $\mathrm{Hu}$ man-Machine Interplay-Building Resilience, Redefining Value Networks and Enabling Meaningful Experiences (UNITE)" for financial support (Decision Number 337655).

\section{OPEN ACCESS}

This article is licensed under a Creative Commons Attribution 4.0 International License, which permits use, sharing, adaptation, distribution and reproduction in any medium or format, as long as you give appropriate credit to the original author(s) and the source, provide a link to the Creative Commons licence, and indicate if changes were made. The images or other third party material in this article are included in the article's Creative Commons licence, unless indicated otherwise in a credit line to the material. If material is not included in the article's Creative Commons licence and your intended use is not permitted by statutory regulation or exceeds the permitted use, you will need to obtain permission directly from the copyright holder. To view a copy of this licence, visit $h$ ttp://creativecommons.org/licenses/by/4.0/.

\section{FUNDING}

Open access funding provided by University of Eastern Finland (UEF) including Kuopio University Hospital.

\section{DATA AVAILABILITY}

Primary vegetation composition data are stored at the Pangaea Data Library (Kokkonen and others 2019a, b, https://doi.org/10.1594/PANGAEA.9042 56). Other data (plant photosynthesis, species-wise leaf area index and tree stand data) are stored in the IDA (ida.fairdata.fi) research data storage service (Laine-Petäjäkangas 2022, https://doi.org/10. 23729/b6e83383-8720-406e-8fd0-4a2094ade983).

\section{REFERENCES}

Adkinson AC, Syed KH, Flanagan LB. 2011. Contrasting responses of growing season ecosystem $\mathrm{CO}_{2}$ exchange to variation in temperature and water table depth in two peatlands in northern Alberta, Canada. Journal of Geophysical Re- 
search: Biogeosciences. https://doi.org/10.1029/2010J G001512.

Ågren GI, Wetterstedt JÅM, Billberger MFK. 2012. Nutrient limitation on terrestrial plant growth-modeling the interaction between nitrogen and phosphorus. New Phytol 194:953960.

Aurela M, Riutta T, Laurila T, Tuovinen JP, Vesala T, Tuittila E-S, Rinne J, Haapanala S, Laine J. 2007. $\mathrm{CO}_{2}$ exchange of a sedge fen in southern Finland-the impact of a drought period. Tellus, Series b: Chemical and Physical Meteorology 59:826837. https://doi.org/10.1111/j.1600-0889.2007.00309.x.

Ballantyne DM, Hribljan JA, Pypker TG, Chimner RA. 2014. Long-term water table manipulations alter peatland gaseous carbon fluxes in Northern Michigan. Wetl Ecol Manag 22:3547.

Basu S, Ramegowda V, Kumar A, Pereira A. 2016. Plant adaptation to drought stress. F1000Research 5:1554.

Bengtsson F, Granath G, Rydin H. 2016. Photosynthesis, growth, and decay traits in Sphagnum-a multispecies comparison. Ecology and Evolution 6(10):3325-3341. https://doi.org/10. 1002/ece3.2119.

Bengtsson F, Rydin H, Baltzer JL, Bragazza L, Bu ZJ, Caporn SJ, Dorrepaal E, Flatberg KI, Galanina O, Gałka M, Ganeva A, Granath G. 2021. Environmental drivers of Sphagnum growth in peatlands across the Holarctic region. Journal of Ecology 109:417-431.

Boardman NK. 1977. Comparative photosynthesis of sun and shade plants. Annu Rev Plant Physiol 28:355-377.

Boisvenue C, Running SW. 2006. Impacts of climate change on natural forest productivity-evidence since the middle of the 20th century. Glob Change Biol 12:862-882.

Bu Z, Hans J, Li H, Zhao G, Zheng X, Ma J, Zeng J. 2011. The response of peatlands to climate warming: a review. Acta Ecol Sin 31:157-162.

Cai T, Flanagan LB, Syed KH. 2010. Warmer and drier conditions stimulate respiration more than photosynthesis in a boreal peatland ecosystem: analysis of automatic chambers and eddy covariance measurements. Plant, Cell and Environment 33:394-407. https://doi.org/10.1111/j.1365-3040.2009.02089 .x.

Charman DJ, Beilman DW, Blaauw M, Booth RK, Brewer S, Chambers FM, Christen JA, Gallego-Sala A, Harrison SP, Hughes PDM, Jackson ST, Korhola A, Mauquoy D, Mitchell FJG, Prentice IC, Van Der Linden M, De Vleeschouwer F, Yu ZC, Alm J, Bauer IE, Corish YMC, Garneau M, Hohl V, Huang Y, Karofeld E, Le Roux G, Loisel J, Moschen R, Nichols JE, Nieminen TM, MacDonald GM, Phadtare NR, Rausch N, Sillasoo U, Swindles GT, Tuittila ES, Ukonmaanaho L, Väliranta M, Van Bellen S, Van Geel B, Vitt DH, Zhao Y. 2013. Climaterelated changes in peatland carbon accumulation during the last millennium. Biogeosciences 10:929-944.

Chimner RA, Pypker TG, Hribljan JA, Moore PA, Waddington JM. 2017. Multi-decadal Changes in Water Table Levels Alter Peatland Carbon Cycling. Ecosystems 20:1042-1057.

Chivers MR, Turetsky MR, Waddington JM, Harden JW, McGuire AD. 2009. Effects of experimental water table and temperature manipulations on ecosystem $\mathrm{CO}_{2}$ fluxes in an Alaskan rich fen. Ecosystems 12:1329-1342.

Churchill AC, Turetsky MR, McGuire AD, Hollingsworth TN. 2015. Response of plant community structure and primary productivity to experimental drought and flooding in an Alaskan fen 1. Can J for Res 45:185-193.
Clymo RS. 1984. The limits to peat bog growth. Philos Trans R Soc Lond B Biol Sci 303:605-654.

Davis MA, Grime JP, Thompson K. 2000. Fluctuating resources in plant communities: a general theory of invasibility. Journal of Ecology 88:528-534. https://doi.org/10.1046/j.1365-2745. 2000.00473.x.

Dimitrov DD, Bhatti JS, Grant RF. 2014. The transition zones (ecotone) between boreal forests and peatlands: ecological controls on ecosystem productivity along a transition zone between upland black spruce forest and a poor forested fen in central Saskatchewan. Ecol Model 291:96-108.

Dimitrov DD, Grant RF, Lafleur PM, Humphreys ER. 2011. Modeling the effects of hydrology on gross primary productivity and net ecosystem productivity at Mer Bleue bog. Journal of Geophysical Research 116:G04010. https://doi.org/ 10.1029/2010JG001586.

Donat MG, Lowry AL, Alexander LV, O'Gorman PA, Maher N. 2016. More extreme precipitation in the world's dry and wet regions. Nat Clim Change 6:508-513.

Dray S, Siberchicot MA. 2017. Package 'ade4'. France: Université de Lyon.

Eskelinen A, Harrison SP. 2015. Resource colimitation governs plant community responses to altered precipitation. PNAS 112(42):13009-13014. https://doi.org/10.1073/pnas.1508170 112.

Evans CD, Peacock M, Baird AJ, Artz RRE, Burden A, Callaghan N, Chapman PJ, Cooper HM, Coyle M, Craig E, Cumming A, Dixon S, Gauci V, Grayson RP, Helfter C, Heppell CM, Holden J, Jones DL, Kaduk J, Levy P, Matthews R, McNamara NP, Misselbrook T, Oakley S, Page SE, Rayment M, Ridley LM, Stanley KM, Williamson JL, Worrall F, Morrison R. 2021. Overriding water table control on managed peatland greenhouse gas emissions. Nature 593:548-552.

Fatichi S, Leuzinger S, Körner C. 2014. Moving beyond photosynthesis: from carbon source to sink-driven vegetation modeling. New Phytol 201:1086-1095.

Finnish Meterological Institute. 2017. Open data. Finnish Meteorological Institute. https://en.ilmatieteenlaitos.fi/opendata. Last accessed 01 Aug 2018.

Flanagan LB, Syed KH. 2011. Stimulation of both photosynthesis and respiration in response to warmer and drier conditions in a boreal peatland ecosystem. Global Change Biology 17:22712287. https://doi.org/10.1111/j.1365-2486.2010.02378.x.

Friend DJC. 1984. Shade adaptation of photosynthesis in Coffea arabica. Photosynthesis Research 5:325-334. https://doi.org/ 10.1007/BF00034977.

Gerdol R, Bonora A, Gualandri R, Pancaldi S. 1996. $\mathrm{CO}_{2}$ exchange, photosynthetic pigment composition, and cell ultrastructure of Sphagnum mosses during dehydration and subsequent rehydration. Canadian Journal of Botany 74:726734. https://doi.org/10.1139/b96-091.

Gong J, Wang K, Kellomäki S, Zhang C, Martikainen PJ, Shurpali N. 2012. Modeling water table changes in boreal peatlands of Finland under changing climate conditions. Ecol Model 244:65-78.

Gorham E. 1991. Role in the carbon cycle and probable responses to climatic warming. Ecol Appl 1:182-195.

Grace J, Woolhouse HW. 1970. A physiological and mathematical study of the growth and productivity of a CallunaSphagnum Community. I. Net photosynthesis of Calluna vulgaris L. Hull. J. Appl. Ecol. 7(2):363. https://doi.org/10.2307/ 2401387. 
Granath G, Strengbom J, Breeuwer A, Heijmans MMPD, Berendse F, Rydin H. 2009. Photosynthetic performance in Sphagnum transplanted along a latitudinal nitrogen deposition gradient. Oecologia 159:705-715. https://doi.org/10.1007/s0 0442-008-1261-1.

Griffith T, Sultan SE. 2012. Field-based insights to the evolution of specialization: plasticity and fitness across habitats in a specialist/generalist species pair. Ecol Evol 2:778-791.

Hájek T, Tuittila E-S, Ilomets M, Laiho R. 2009. Light responses of mire mosses-A key to survival after water-level drawdown? Oikos 118:240-250.

Harley PC, Tenhunen JD, Murray KJ, Beyers J. 1989. Irradiance and temperature effects on photosynthesis of tussock tundra Sphagnum mosses from the foothills of the Philip Smith Mountains, Alaska. Oecologia 79:251-259. https://doi.org/10. 1007/BF00388485.

Harris LI, Roulet NT, Moore TR. 2020. Drainage reduces the resilience of a boreal peatland. Environmental Research Communications 2:065001.

Hassel K, Kyrkjeeide MO, Yousefi N, Prestø T, Stenøien HK, Shaw JA, Flatberg KI. 2018. Sphagnum divinum (sp. nov.) and $S$. medium Limpr. and their relationship to $S$. magellanicum Brid. J Bryol 40:197-222.

Heijmans MMPD, Mauquoy D, Van Geel B, Berendse F. 2008. Long-term effects of climate change on vegetation and carbon dynamics in peat bogs. J Veg Sci 19:307-320.

Helbig M, Waddington JM, Alekseychik P, Amiro BD, Aurela M, Barr AG, Black TA, Blanken PD, Carey SK, Chen J, Chi J, Desai AR, Dunn A, Euskirchen ES, Flanagan LB, Forbrich I, Friborg T, Grelle A, Harder S, Heliasz M, Humphreys ER, Ikawa H, Isabelle PE, Iwata H, Jassal R, Korkiakoski M, Kurbatova J, Kutzbach L, Lindroth A, Löfvenius MO, Lohila A, Mammarella I, Marsh P, Maximov T, Melton JR, Moore PA, Nadeau DF, Nicholls EM, Nilsson MB, Ohta T, Peichl $M$, Petrone RM, Petrov R, Prokushkin A, Quinton WL, Reed DE, Roulet NT, Runkle BRK, Sonnentag O, Strachan IB, Taillardat P, Tuittila ES, Tuovinen JP, Turner J, Ueyama M, Varlagin A, Wilmking M, Wofsy SC, Zyrianov V. 2020. Increasing contribution of peatlands to boreal evapotranspiration in a warming climate. Nat Clim Change 10:555-560.

Huner NPA, Öquist G, Sarhan F. 1998. Energy balance and acclimation to light and cold. Trends Plant Sci 3:224-230.

Jassey VEJ, Signarbieux C. 2019. Effects of climate warming on Sphagnum photosynthesis in peatlands depend on peat moisture and species-specific anatomical traits. Glob Change Biol 25:3859-3870.

Kangas L, Maanavilja L, Hájek T, Juurola E, Chimner RA, Mehtätalo L, Tuittila ES. 2014. Photosynthetic traits of Sphagnum and feather moss species in undrained, drained and rewetted boreal spruce swamp forests. Ecol Evol 4:381-396.

Kokkonen NAK, Laine AM, Laine J, Vasander H, Kurki K, Gong J, Tuittila E-S. 2019a. Responses of peatland vegetation to 15year water level drawdown as mediated by fertility level. J Veg Sci 30:1206-1216.

Kokkonen NAK, Laine AM, Laine J, Vasander H, Kurki K, Gong J, Tuittila E-S. 2019b. Responses of peatland vegetation to 15year water level drawdown as mediated by fertility level. PANGAEA. https://doi.org/10.1594/PANGAEA.904256. Supplement to: Kokkonen, NAK et al. 2019. Responses of peatland vegetation to 15-year water level drawdown as mediated by fertility level. Journal of Vegetation Science, 30(6):12061216. https://doi.org/10.1111/jvs.12794.
Korrensalo A, Alekseychik P, Hájek T, Rinne J, Vesala T, Mehtätalo L, Mammarella I, Tuittila ES. 2017. Species-specific temporal variation in photosynthesis as a moderator of peatland carbon sequestration. Biogeosciences. https://doi.org/10. 5194/bg-14-257-2017.

Korrensalo A, Hájek T, Vesala T, Mehtätalo L, Tuittila ES. 2016. Variation in photosynthetic properties among bog plants. Botany 94:1127-1139. https://doi.org/10.1139/cjb-2016-011 7.

Laine AM, Byrne KA, Kiely G, Tuittila ES. 2009. The short-term effect of altered water level on carbon dioxide and methane fluxes in a blanket bog. Suo 60:65-83.

Laine AM, Ehonen S, Juurola E, Mehtätalo L, Tuittila ES. 2015. Performance of late succession species along a chronosequence: environment does not exclude Sphagnum fuscum from the early stages of mire development. Journal of Vegetation Science 26:291-301. https://doi.org/10.1111/jvs.12231.

Laine AM, Lindholm T, Nilsson M, Kutznetsov O, Jassey VEJ, Tuittila ES. 2021. Functional diversity and trait composition of vascular plant and Sphagnum moss communities during peatland succession across land uplift regions. Journal of Ecology 109:1774-1789. https://doi.org/10.1111/1365-2745. 13601.

Laine AM, Mäkiranta P, Laiho R, Mehtätalo L, Penttilä T, Korrensalo A, Minkkinen K, Fritze H, Tuittila E. 2019. Warming impacts on boreal fen $\mathrm{CO}_{2}$ exchange under wet and dry conditions. Glob Change Biol 25:1995-2008.

Laine AM, Tolvanen A, Mehtätalo L, Tuittila E. 2016. Vegetation structure and photosynthesis respond rapidly to restoration in young coastal fens. Ecol Evol 6:6880-6891.

Laine J, Vasander H, Laiho R. 1995. Long-term effects of water level drawdown on the vegetation of drained pine mires in southern Finland. Journal of Applied Ecology 32:785-802. h ttps://doi.org/10.2307/2404818.

Laine-Petäjäkangas A. 2022. Dataset supporting the manuscript "Two mechanisms drive changes in boreal peatland photosynthesis following long-term water level drawdown: species turnover and altered photosynthetic capacity". Version $1 . \mathrm{h}$ ttps://doi.org/10.23729/b6e83383-8720-406e-8fd0-4a2094ad e983

Legendre P. 2019. A temporal beta-diversity index to identify sites that have changed in exceptional ways in space-time surveys. Ecol Evol 9:3500-3514.

Legendre P, Condit R. 2019. Spatial and temporal analysis of beta diversity in the Barro Colorado Island forest dynamics plot. Panama. for Ecosyst 6:7.

Leppälä M, Laine AM, Seväkivi ML, Tuittila ES. 2011. Differences in $\mathrm{CO}_{2}$ dynamics between successional mire plant communities during wet and dry summers. Journal of Vegetation Science 22:357-366. https://doi.org/10.1111/j.1654-11 03.2011.01259.x.

Lloyd J, Farquhar GD. 1996. The $\mathrm{CO}_{2}$ dependence of photosynthesis, plant growth responses to elevated atmospheric $\mathrm{CO}_{2}$ concentrations and their interaction with soil nutrient status. I. General principles and forest ecosystems. Functional Ecology 10:4-32. https://doi.org/10.2307/2390258.

Loach K. 1967. Shade tolerance in tree seedlings. I. Leaf photosynthesis and respiration in plants raised under artificial shade. New Phytologist 66:607-621.

Loisel J, Gallego-Sala AV, Amesbury MJ, Magnan G, Anshari G, Beilman DW, Benavides JC, Blewett J, Camill P, Charman DJ, Chawchai S, Hedgpeth A, Kleinen T, Korhola A, Large D, Mansilla CA, Müller J, van Bellen S, West JB, Yu Z, Bubier JL, 
Garneau M, Moore T, Sannel ABK, Page S, Väliranta $M$, Bechtold M, Brovkin V, Cole LES, Chanton JP, Christensen TR, Davies MA, De Vleeschouwer F, Finkelstein SA, Frolking S, Gałka M, Gandois L, Girkin N, Harris LI, Heinemeyer A, Hoyt AM, Jones MC, Joos F, Juutinen S, Kaiser K, Lacourse T, Lamentowicz M, Larmola T, Leifeld J, Lohila A, Milner AM, Minkkinen K, Moss P, Naafs BDA, Nichols J, O'Donnell J, Payne R, Philben M, Piilo S, Quillet A, Ratnayake AS, Roland TP, Sjögersten S, Sonnentag O, Swindles GT, Swinnen W, Talbot J, Treat C, Valach AC, Wu J. 2021. Expert assessment of future vulnerability of the global peatland carbon sink. Nat Clim Change 11:70-77.

Mäkilä H, Saarnisto M. 2008. No Title. In: Strack M, editor. Peatlands and Climate Change. International Peat Society. pp 24-43.

Mehtätalo L, Lappi J. 2020. Biometry for forestry and environmental data. Series: Chapman Charman Hall/CRC applied environmental statistics. Boca Raton, FL: CRC Press.

Minkkinen K, Vasander H, Jauhiainen S, Karsisto M, Laine J. 1999. Post-drainage changes in vegetation composition and carbon balance in Lakkasuo mire, Central Finland. Plant Soil 207:107-120.

Munir TM, Khadka B, Xu B, Strack M. 2017. Mineral nitrogen and phosphorus pools affected by water table lowering and warming in a boreal forested peatland. Ecohydrology 10:e1893.

Munir TM, Perkins M, Kaing E, Strack M. 2015. Carbon dioxide flux and net primary production of a boreal treed bog: responses to warming and water-table-lowering simulations of climate change. Biogeosciences 12:1091-1111.

Munir TM, Xu B, Perkins M, Strack M. 2014. Responses of carbon dioxide flux and plant biomass to water table drawdown in a treed peatland in Northern Alberta: a climate change perspective. Biogeosciences 1 1:807-820.

Nichols JE, Peteet DM. 2019. Rapid expansion of northern peatlands and doubled estimate of carbon storage. Nat Geosci 12:917-921.

Nijp JJ, Limpens J, Metselaar K, van der Zee SEATM, Berendse F, Robroek BJM. 2014. Can frequent precipitation moderate the impact of drought on peatmoss carbon uptake in northern peatlands? New Phytol 203:70-80.

Oechel WC, Vourlitis GL, Hastings SJ, Ault RP, Bryant P. 1998. The effects of water table manipulation and elevated temperature on the net $\mathrm{CO}_{2}$ flux of wet sedge tundra ecosystems. Glob Change Biol 4:77-90.

Peichl M, Öquist M, Ottosson Löfvenius M, Ilstedt U, Sagerfors J, Grelle A, Lindroth A, Nilsson MB. 2014. A 12-year record reveals pre-growing season temperature and water table level threshold effects on the net carbon dioxide exchange in a boreal fen. Environmental Research Letters 9:055006. http s://doi.org/10.1088/1748-9326/9/5/055006.

Peltoniemi K, Laiho R, Juottonen H, Bodrossy L, Kell DK, Minkkinen K, Mäkiranta P, Mehtätalo L, Penttilä T, Siljanen HMP, Tuittila E-S, Tuomivirta T, Fritze H. 2016. Responses of methanogenic and methanotrophic communities to warming in varying moisture regimes of two boreal fens. Soil Biology and Biochemistry 97:144-156.

Peltoniemi K, Laiho R, Juottonen H, Kiikkilä O, Mäkiranta P, Minkkinen K, Pennanen T, Penttilä T, Sarjala T, Tuittila ES, Tuomivirta T, Fritze H. 2015. Microbial ecology in a future climate: effects of temperature and moisture on microbial communities of two boreal fens. FEMS Microbiol Ecol. http s://doi.org/10.1093/femsec/fiv062.
Rannik Ü, Launiainen S, Pumpanen J, Kulmala L, Kolari P, Vesala T, Korhonen JF, Hari P. 2013. Environmental factors. In: Hari P, Heliövaara K, Kulmala L, Eds. Physical and physiological forest ecology, . Dordrecht: Springer. pp 27-42.

Repola J. 2008. Biomass equations for birch in Finland. Silva Fennica 42:605-624.

Repola J. 2009. Biomass equations for Scots pine and Norway spruce in Finland. Silva Fennica 43:625-647.

Rinne J, Tuovinen J-P, Klemedtsson L, Aurela M, Holst J, Lohila A, Weslien P, Vestin P, Łakomiec P, Peichl M, Tuittila E-S, Heiskanen L, Laurila T, Li X, Alekseychik P, Mammarella I, Ström L, Crill P, Nilsson MB. 2020a. Effect of the 2018 European drought on methane and carbon dioxide exchange of northern mire ecosystems. Philos Trans R Soc B Biol Sci 375:20190517.

Rinne J, Tuovinen JP, Klemendtsson L, Aurela M, Holst J, Lohila A, Weslien P, Vestin P, Peichl M, Tuittila ES, Nilsson MB. 2020b. Effect of the 2018 European drought on methane and carbon dioxide exchange of northern mire ecosystems. Philosophical Transactions of the Royal Society B 375:20190517.

Riutta T, Laine J, Tuittila E-S. 2007. Sensitivity of CO2 exchange of fen ecosystem components to water level variation. Ecosystems 10:718-733.

Roberts MR, Gilliam FS. 1995. Disturbance effects on herbaceous layer vegetation and soil nutrients in Populus forests of northern lower Michigan. Journal of Vegetation Science 6:903-912. https://doi.org/10.2307/3236405.

Roulet NT, Moore TR, Bubier JL, Lafleur PM. 1992. Northern fens: methane flux and climatic change. Tellus B 44:100-105.

Rydin H, Jeglum JK. 2013. The Biology of Peatlands. Oxford: Oxford University Press. https://doi.org/10.1093/acprof:osobl/ 9780199602995.001.0001.

Rydin H, McDonald AJS. 1985. Photosynthesis in Sphagnum at different water contents. Journal of Bryology 13:579-584. h ttps://doi.org/10.1179/jbr.1985.13.4.579.

Sarkkola S, Hökkä H, Penttilä T. 2004. Natural development of stand structure in peatland scots pine following drainage: results based on long-term monitoring of permanent sample plots. Silva Fennica 38:405-412.

Schipperges B, Rydin H. 1998. Response of photosynthesis of Sphagnum species from contrasting microhabitats to tissue water content and repeated desiccation. New Phytologist 140:677-684. https://doi.org/10.1046/j.1469-8137.1998.0031 1.x.

Small E. 1972. Photosynthetic rates in relation to nitrogen recycling as an adaptation to nutrient deficiency in peat bog plants. Can. J. Bot. 50(11):2227-2233. https://doi.org/10.113 9/b72-289.

Smith WK, Vogelmann TC, DeLucia EH, Bell DT, Shepherd KA. 1997. Leaf form and photosynthesis. BioScience 47:785-793.

Smolander H, Lappi J. 1985. Integration of a nonlinear function in a changing environment: estimating photosynthesis using mean and variance of radiation. Agric for Meteorol 34:83-91.

Strack M, Waddington JM. 2007. Response of peatland carbon dioxide and methane fluxes to a water table drawdown experiment. Glob Biogeochem Cycles. https://doi.org/10.102 9/2006GB002715.

Strack M, Waddington JM, Rochefort L, Tuittila E-S. 2006. Response of vegetation and net ecosystem carbon dioxide exchange at different peatland microforms following water table drawdown. J Geophys Res Biogeosciences 111:1-10. 
Strack M, Waddington JM, Tuittila E-S. 2004. Effect of water table drawdown on northern peatland methane dynamics: implications for climate change. Glob Biogeochem Cycles 18:1-7.

Straková P, Penttilä T, Laine J, Laiho R. 2012. Disentangling direct and indirect effects of water table drawdown on aboveand belowground plant litter decomposition: consequences for accumulation of organic matter in boreal peatlands. Glob Change Biol 18:322-335.

Sultan SE. 1995. Phenotypic plasticity and plant adaptation. Acta Botanica Neerlandica 44:363-383.

Swindles GT, Morris PJ, Mullan DJ, Payne RJ, Roland TP, Amesbury MJ, Lamentowicz M, Turner TE, Gallego-Sala A, Sim T, Barr ID, Blaauw M, Blundell A, Chambers FM, Charman DJ, Feurdean A, Galloway JM, Gałka M, Green SM, Kajukało K, Karofeld E, Korhola A, Lamentowicz Ł, Langdon P, Marcisz K, Mauquoy D, Mazei YA, McKeown MM, Mitchell EAD, Novenko E, Plunkett G, Roe HM, Schoning K, Sillasoo Ü, Tsyganov AN, van der Linden M, Väliranta M, Warner B. 2019. Widespread drying of European peatlands in recent centuries. Nat Geosci 12:922-928.

Talbot J, Roulet NT, Sonnentag O, Moore TR. 2014. Increases in aboveground biomass and leaf area 85 years after drainage in a bog. Botany 92:713-721. https://doi.org/10.1139/cjb-20130319 .

Turunen J, Tomppo E, Tolonen K, Reinikainen A. 2002. Estimating carbon accumulation rates of undrained mires in
Finland-application to boreal and subarctic regions. The Holocene 12:69-80.

Waddington JM, Morris PJ, Kettridge N, Granath G, Thompson DK, Moore PA. 2015. Hydrological feedbacks in northern peatlands. Ecohydrology 8:113-127.

Weltzin JF, Pastor J, Harth C, Bridgham SD, Updegraff K, Chapin CT. 2000. Response of bog and fen plant communities to warming and water table manipulations. Ecology 81:34643478.

Westman CJ, Laiho R. 2003. Nutrient dynamics of drained peatland forests. Biogeochemistry 63:269-298.

Whittington PN, Price JS. 2006. The effects of water table drawdown (as a surrogate for climate change) on the hydrology of a fen peatland, Canada. Hydrol Process 20:3589-3600.

Yrjälä $\mathrm{K}$, Tuomivirta $\mathrm{T}$, Juottonen $\mathrm{H}$, Putkinen A, Lappi $\mathrm{K}$, Tuittila ES, Penttilä T, Minkkinen K, Laine J, Peltoniemi K, Fritze H. 2011. CH4 production and oxidation processes in a boreal fen ecosystem after long-term water table drawdown. Glob Change Biol 17:1311-1320.

Yu Z, Beilman DW, Frolking S, MacDonald GM, Roulet NT, Camill P, Charman DJ. 2011. Peatlands and their role in the global carbon cycle. Eos Trans Am Geophys Union 92:97-98.

Zhang H, Amesbury MJ, Piilo SR, Garneau M, Gallego-Sala A, Väliranta MM. 2020. Recent changes in peatland testate amoeba functional traits and hydrology within a replicated site network in Northwestern Québec, Canada. Front Ecol Evol 8:1-12. 